\title{
Ephemeral Mobility: Critical Appraisal of the facets of Indian Migration and the Maistry meditations in Burma (c. 1880-1940) ${ }^{1}$
}

RITESH KUMAR JAISWAL ${ }^{2} ;$

\section{Abstract}

The significance of Burma to the history of global and Indian migration can be understood by the fact that it was the destination accounting for the largest mobility of Indian migrants during the century 1830s-1930s. This article is an attempt to complicate the parameters which have conventionally defined the characteristics of Indian migration during the colonial period. Broadly, it is also attempted to challenge and deconstruct the Eurocentric perceptions on non-European migrations in the global migration framework, by focussing on the quality, quantity, stimulating agency and nature of the colonial Indian migration. To do so, the article delves into analysing the content, pattern, nature and functioning of the informally regulated Maistry system, which mediated the recruitment of Indian labour and their supervision in Burma through networks of 'kin-intermediary' called Maistry.

Indian labour, Indian Migration, Burma, Rangoon, Maistry system, Free/Un-free Mobility, Rice plantations, Chettiyar, Debt-bondage, Advances, Promissory notes and Contract.

1 University of Delhi, Delhi - Índia.

2 I am immensely thankful to the Professors and Colleagues at the: Dept. of History, University of Delhi; CeMIS, Gottingen University, where I was a Global History Fellow from Jan-June 2017; and WIGH, Harvard University where I remain as a Fulbright-Nehru Fellow. I would also like to thank: Institute for New Economic Thinking (INET) and the Joint Centre for History and Economics at Harvard and Cambridge University for the "History Project" Research grant, and the Charles Wallace India Trust for the Research Fellowship which helped me pursue my archival work. Draft of this article was presented at USP, Sao Paulo, Brazil, March 2016, and Binghamton University, New York, November 2017. I'm thankful to the commentators for their feedback.

3 B.A (Hons) History, M.A History, M.Phil History - University of Delhi, India. Ph.D Candidate, Department of History, University of Delhi. Fulbright-Nehru Fellow, Weatherhead Initiative on Global History, Harvard University. Current, Ph.d Candidate, Department of History, University of Delhi. Fulbright-Nehru Fellow at Weatherhead Initiative on Global History, Harvard University (Completed my tenure in June 2018). Contact: riteshjais@gmail.com. 


\section{Mobilidade efêmera: uma avaliação crítica das facetas da migração indiana e as mediações maistry em Burma (c. 1880-1940)}

RITESH KUMAR JAISWAL

\section{Resulino}

O significado de Burma para a história global e indiana da migração pode ser entendido pelo fato de ser este um destino dominante entre os migrantes indianos entre as décadas de 1830 e 1930. Este artigo apre-senta um esforço de complexificação dos parâmetros convencionalmen-te definidores das características da migração indiana durante o perío-do colonial. De modo mais amplo, é também um esforço de desafiar e desconstruir percepções eurocêntricas de migrações não-européias em perspectiva global, focando na qualidade, na quantidade, na agência estimuladora e na natureza da migração indiana colonial. Para tanto, o artigo perscruta conteúdo, padrão, natureza e funcionamento do siste-ma maistry, informalmente regulado, e que mediou o recrutamento e a supervisão de trabalho indiano em Burma.

\section{Palavras-chave}

Índia colonial; Trabalho indiano; migração indiana; Burma; Rangoon; sistema maistry. 
In the historiography on Indian migration there has been a strong tendency to view colonial migration as largely indentured in form, coercive and un-free in nature, stimulated mainly through the agency of Europeans, predominantly Northern Indian or Bhojpuri region as its source, plantation labour as its composition, and the British overseas colonies in the Caribbean and the Pacific as its region of production. Such an approach completely neglects the multidimensional nature of Indian emigration as it existed in the nineteenth and the twentieth century.

One of the key reasons for generation of such a tendency was that the colonial state in India was explicitly involved in regulating the Indenture system, resulting in copious documentation of the system. While the 'other' system of Indian emigration- Kangani and Maistrywhich prevailed in the Indian Ocean/Bay of Bengal destinations of Ceylon, Burma and the Malayan peninsula was less formally regulated and thus relatively lesser documented. The documentary sparseness vis-à-vis the Indenture system as well as incongruities in the records available, explains to a large extent the neglect of the study of Kangani and Maistry system of migration. However, to understand the significance of these systems it is worthwhile to note that in magnitude, the non-indentured migration was far more voluminous than indentured migration. The total emigration from India in between 1834 to 1937 has been estimated at 30 million out of which emigration to Burma, Ceylon and Malaya, which took place largely through Kangani and Maistry systems, accounted for over 90 percent of the total. ${ }^{4}$

The significance of colonial Burma ${ }^{5}$ to the history of Indian and global migratory flows can be measured by the fact that it was the destination accounting for maximum mobility of Indian migrants i.e. approximately 15 million individuals, during the century 1830s-1930s.

4 Davis, Kingsley, Population of India and Pakistan, PUP, 1951 (Part on Migration); For a further discussion over volume of migrants vide Northrup, David, Indentured Labour in the Age of Imperialism (1834-1922), CUP, 1995, pp. 64.

5 Currently known as Myanmar after the ruling Military junta changed its name in 1989. 
However, its overwhelming numerical significance is ironically matched by academic neglect in equal measure. This article will attempt to scrutinize and reappraise the parameters which have conventionally defined the characteristics of Indian migration during the nineteenth and twentieth century. I will attempt to do so by exploring the intricate pattern, functioning and nature of the Indian emigration to Burma which took place largely under Maistry's informal regulations and defined the mobility of millions of Indians.

On the other hand, studies on global migratory patterns have, in multiple ways, otherised and largely underestimated the immense significance, phenomenal mobility and the multidimensionality of the non-European/Asian migration during the colonial period vis-à-vis the transatlantic flows. For example, we notice the "otherization" of the Asian migration patterns as mainly Indentured, coercive and bonded in its nature, and as distinct from the European free migration. It is also noticed that overarching significance is accorded to transatlantic migrations which were viewed as quantitatively significant, and integral to the expansion and integration of the world economy. While the non-European migrations were viewed as a direct product of European intervention and expansion. ${ }^{6}$ The aim of this article is to deconstruct and complicate Eurocentric assumptions on the Indian (non-European) migrations in the framework of global migration studies.

\section{Contextualizing the Beginnings}

India's early encounter with Burma as per the Indian and Burmese chronicles and lore is believed to date back to the prehistoric period when the civilization was still in the cradle. The archaeological findings coupled with literary analysis tend to authenticate it further as they speak of diverse streams of early Indian emigration from di-

6 For a detailed discussion see Mckeown, Adam, 'Global Migration' (1846-1940), Journal of World History, Volume 15, Number 2, University of Hawai'i Press, June 2004. 
fferent regions of India. ${ }^{7}$ These early Indian immigrants in Burma were mainly princes, including those banished from their country, merchants, fortune-seekers and adventurers. Their mobility was largely guided by politico-economic ambitions, and the desire to spread the religious word. However, the pattern of Indian emigration and the system of its operation faced radical transformations with the British annexation of Burma in the early nineteenth century.

The strategic intent of the British to construct a buffer-zone between south Asia and China, against French activities in Indo-China and Thailand, and the desire to safeguard its far-eastern trade and empire from the intrusive sovereignty exercised by Burmese kingdoms in the bordering areas of British Bengal i.e. Assam, Manipur and Arakan, provided the British with a motive to conquer Burma. ${ }^{8}$ The three Anglo-Burmese wars, which brought about the stage-wise annexation of Burma in between 1824-1885, clubbed together with a multitude of local and global factors discussed ahead, opened up Burma to the western world and its huge demand for Burmese rice.

The opening of the Suez Canal in 1869 was followed by the transport revolution characterised by wide-scale application of new technologies like the steamships, metalled roads and railways. Ships built of iron or steel, instead of wood, could carry three to four times as much cargo over the year (ton-miles) as the ships of 1850's. The ship freights to the Far East also experienced spectacular falls, especially after the opening of Suez Canal. The technique of making good metalled roads which were mastered in Europe spread to regions of Burma, Malaya and Ceylon by the 1880's. ${ }^{9}$ Moreover, the rising industrial

7 Majumdar, R.C, Ancient Indian Colonization in South-East Asia, Baroda, Oriental Institute, 1955; Hall, D. G. E., A History of South-East Asia, New York: St. Martin's Press, 1955.

8 Chakravarti, N.R, The Indian Minority in Burma: The Rise and Decline of An Immigrant Community, OUP, London, 1971, pp. 6; Tinker, Hugh, The Banyan Tree: Overseas Emigrants from India, Pakistan and Bangladesh, OUP, 1977, Chapter-5.

9 Lewis, W. Arthur (ed.), Tropical Development 1880-1913, Studies in Economic Progress, Gresham Press, Great Britain, 1970. However, one can't undermine the fact that the environmental factors, especially the monsoons, continued to remain a decisive factor regulating productivity, prices 
and finance capitalism generated an intense demand for investment of surplus capital in the 'free markets' of the colonies. All these developments gave real pace to flow of goods, capital, men and ideas.

The 1880's was also marked by sugar crisis in West Indies colonies which led to a decline in Indian overseas emigration and revenues for the British. It necessitated the promotion of emigration to colonies independent of sugar as the demand for other tropical produce increased at the same pace as the world trade. The market was especially buoyant for coffee, cocoa, tobacco, cotton, tea, coconut oilseeds, rubber and rice. There was also strong demand for rice in tropical countries itself to feed the workers producing a commercial crop. Within these broader global settings, the British colonies in the Bay rim-Burma, Ceylon and Malaya- which were sparsely populated fertile hotspots for production of various cash crops caught sight of officials and capitalists as good investment grounds. ${ }^{10}$

Labour was an essential facet to generate value to the capital and pursue the development of Burma. The Irrawaddy delta, which was the most fertile part of Burma, was largely a sparsely populated wasteland and Rangoon, a marshy little waterfront. Labourers were required as hewers of wood, clearers of jungles, and cultivators for the southern rice cultivating zones. They were also necessary for multitudes of connected tasks which involved heavy earth moving, filling in of swamps, raising of land above flood levels, construction of roads, drainage, sites for building etc. More importantly, labour was required for tasks connected with the emerging export-oriented rice cultivation such as packing, loading, transporting, bagging, weighing etc, which in turn necessitated the development of shipping

and mobility, vide Amrith, Sunil, Crossing the Bay of Bengal: The furies of Nature and Fortunes of Migrants, Harvard University Press, USA, 2013.

10 Ceylon for coffee, tea and rubber plantations, Malaya for Rubber and Sumatra for tobacco were other places where Indian labour emigration was being encouraged, Emigration of Tamils from Ceylon to Sarawak, R\&A Dept., Emigration Branch, Fno. 75 of 1886, Pros. No. 12-14, Jan 1887, NAI; Lewis (1970), ibid., Chapter 1. 
Industry as well as several other undeveloped and underdeveloped commercial and industrial enterprises in Burma. ${ }^{11}$

The first and second Anglo-Burmese war saw the influx Indians who were primarily traders, sepoys in colonial troops, who had been an integral part of the British conquest of Burma, ${ }^{12}$ sailors, civil servants, and labourers. The migrants of this phase were largely labelled as the "camp followers" of the British. Labour needs for the expanding rice cultivation in the southern regions were initially met by the migrant labourers from the northern Burma. However, this proved to be insufficient to meet the burgeoning labour demands for cultivation as well as exports. Indian migration to Burma had begun as early as 1830's however, it acquired greater momentum only by the 1880's when British consolidated their rule in Burma. The 1872 census shows Indians in Burma cumulated to only 16000 individuals. ${ }^{13}$

In 1872, merchants of Rangoon presented Lord Mayo with a memorial stating the requirements of British Burma for new immigrant labourers due to shortage within. He sought an enactment of a contract law to regulate the mobility and productivity of immigrant labourers..$^{14}$ In 1874 , the colonial state had tried to settle a class of zamindar-agriculturalist from Bihar by entrusting upon them land grants which wasn't much successful. In 1876, efforts were made to promote emigration under the Burma Labour Act by appointing a recruiting

11 An irony in this case is the evidence of importing Burmese families for settlement as forest labourers in South Andaman by the colonial government. Moreover, there are also evidences of emigration of skilled Burmese women for employment in Penang and Straits as cheroot makers, Cost of importing families from Burma for settlement as forest labourers in South Andaman, EHL, Forests Branch, Pros. No. 135-139-B, Sep 1926, NAI; Emigration of Skilled labourers under the provision of Indian Emigration Act from port of Moulmein, EHL, Overseas Branch, Pros. No. 62-64-B, 1928 May, NAI.

12 'Colonial Auxiliaries' of many South Asian Ethnicities were a vital component of British control and development, Dirk Hoerder, Dirk, Cultures in Contact: World Migrations in the Second Millennium, Durham, N.C.: Duke University Press, 2002.

13 The census covered only lower Burma where the British administration was gradually being setup, Chakravarti (1971), op. cit., p 8, 13.

14 Want felt in British Burma for a contract law for imported labourers, Revenue, Agriculture and Commerce Dept., Emigration Branch, April 1872, NAI. 
agent and setting up Coconada Recruiting Agency in East Godavari district of Madras Presidency. However, the scheme was not successful because of multiple reasons, the most important being that none of the mills in Rangoon applied for labourers from these depots. They recruited their labourers through the native contractors or Maistries, which was thought to be easier to manage..$^{15}$ Another scheme was introduced under Ashley Eden in 1874 to promote emigration to Burma from the famine struck areas of Bengal. It was also a failure and subsequently abandoned. ${ }^{16}$

Colonial government, however, continued with efforts to promote Indian labour emigration by the introduction of fortnightly/ weekly steamer services in 1870's from the Coromandel coast. It also offered subsidies to the Indian shipping companies for the carrying of Indian migrants to Burma, apart from the shipping companies reducing fares to increase traffic. Roads and communication network from Chittagong to Akyab and other parts of Arakan were also being improved to promote brisk emigration via. land route. ${ }^{17}$ The flows increased, however, the investors and employers in Burma remained eager to obtain more labourers.

In British India, the agricultural labourers continued to face degrading socio-economic and environmental conditions marked by exploitative land revenue structure, landlessness, recurrent famines, epidemics all of which pushed them in the more deeper structure of bondage and starvation. Caste restrictions excluded them from multifarious occupations and modes of diversifying subsistence. Migra-

15 Unlicensed recruiting of labour in Madras for British Burma, Revenue, Agriculture and Commerce Dept., Emigration Branch, 1878, NAI. Emigration to Burma, R\&A Dept., Emigration Branch, 1882, NAI; Repeal of Act III of 1876- The British Burma Labour Law, R\&A Dept., Emigration Branch, 1883, NAI.

16 Emigration to Burma, R\&A Dept., Emigration Branch, Feb 1882, NAI; Repeal of Act III of 1876- The British Burma Labour Law, R\&A Dept., Emigration Branch, Oct 1883, NAI.

17 However, Tinker argues that the British to preserve the buffer role played by Burma between South Asia and China and against French activity in Indo-China and Thailand did not develop land and Railway communication between India and Burma, Tinker (1977), op. cit., p. 140. 
tion within this scenario emerged as the great escape to fulfil their luring dreams of better socio-economic life. Regular employment, higher wages, better health and living conditions, freedom from caste restrictions were some key aspirations. Burma's geographical proximity, the rising demands, and presumed comfort of recruitment and work under the 'kin-networks' of family and friends also played a crucial role in marking the beginning of a large-scale influx of Indian labourers to Burma. Indian labourers mediated by the maistries arrived in huge numbers for carrying on formidable hard manual work for the development of Burma. The rising tide of labour migration was a significant feature of Indian presence in Burma. Rangoon developed as one of the most well-planned cities in the east, a major port, ranking high with Bombay and Calcutta, and the capital of Burma. ${ }^{18}$ Over the years after British annexation, it emerged as the centre of world's rice production, and the most prosperous and thickly populated area in Burma.

With the intense amount of capital investment and rising tide of migration, Burma experienced a stage of agricultural and industrial transition. New mills were built up, mining areas were enlarged, transport system expanded, and a number of new industries came into existence like the wood, chemicals, oil, food, apart from rice. Industrial progress was built on the foundation laid by the improvement and expansion of agriculture which was the predominant industry of the Burmese, and the mainstay of her commerce. The acreage of paddy in lower Burma increased from 2,848 thousand acres annual average in between 1876-80 to an annual average of 9,593 thousand acres in between 1926-30. The exports of paddy and rice increased from an annual average of 0.381 million tons in between 1870-1880 to an annual average of 2.906 in between 1925 to $1929 .{ }^{19}$ The exports

18 Chakravarti (1971), op. cit., p. 7-8.

19 Brown, Ian, Colonial Economy in Crisis: Burma's rice cultivators and World Depression of 1930s, Routledge Curzon, London and New York, 2005, Chapter 1 and 2. 
continuously increased up till 1930, except for a brief fall during the WWI which was recovered by early 1920 .

Moreover, apart from the production and circulation of Burmese rice, the cultivation and exports of Ceylonese tea and rubber, Malayan rubber, and Sumatran tobacco also increased phenomenally. The export from far-eastern rice growing peasant economies- Burma, Thailand, China, Indo-china multiplied by four to five times. In between 1883-1913, the volume of exports from Ceylon increased from US\$13.9 million to 72.7 million. Majority of the exports were tea, but it also included other cash crops like cocoa, coconut, rubber etc. To all these colonies around the Bay, emigration was encouraged to succeed the global capitalist investments. Indian men, as well as material, were required and commanded, thereby playing a significant role in the transition of their economies. Indian labour demands continued to soar and in between 1900-1938, a total of 11.5 million Indians migrated to Burma. ${ }^{20}$

\section{Labourers source and work-sphere}

The Burmans often referred to the Indians as kala whose etymology can be taken to be derivative of the Burmese words Ka La which meant "foreigner par excellence" or "one coming from overseas". The children of mixed marriages were called Zerbadi or Child of Gold. ${ }^{21}$ The intermarriage between Indian, mainly Muslim men, and Burmese women was despised by the Burmese as it led the offspring to adopt father's religion and lose 'their' religion, inducing a sense

20 Compiled from Confidential Note by Dr. H Bernardelli (Professor and Statistician acting as Secy. to the Baxter Committee), Jan 1940 sent to G.S Bozman, Deputy Secy of GOI, EHL Dept., New Delhi in Burma-Control of Immigration of Unskilled Labourer, (Part-III, pp. 144-298), L\&O Branch, 1938, NAI, pp. 188.

21 Mahajani, Usha The Role of Indian Minorities in Burma and Malaya, Bombay, Vora \& Co., 1960, p. 23; Ferrars, Max and Ferrars, Bertha, Burma, $2^{\text {nd }}$ Edition, London and New York, 1901, p. 159-162; Yegar, Moshe Muslims of Burma - A study of a Minority Group, Heidelberg, 1972, p. 29-36. 
of cultural loss. ${ }^{22}$ The zerbadis, however, preferred to call themselves Burman-Muslims to distinguish themselves from the Burmese in religion, and identify with them otherwise. To get a better sense of the source of Indian migrants, and their sphere of production in Burma one can divide them into six major regional-linguistic groups (See Appendix 1). ${ }^{23}$ An analysis of the table highlights that Indians of different classes and professions, coming predominantly from the districts of peninsular India formed the bulk of migrants to Burma during the British period. Migrants largely comprised of Telugu, Tamil and Uriya labourers coming from Ganjam, Godavari, Vizag, Ramnad, and Tanjore regions of Southern India. Most of them belonged to the lower and 'untouchable' castes, and the agricultural class.

On the other end of the spectrum, were the Chettiars merchant-bankers and moneylenders. The Burma Provincial Banking Enquiry Committee stated the Chettiars are the mainstay of the agricultural finance...without their support, the internal and external trade of the country would break down and the rice crop could not even be produced'. In between 1914-15 to 1924-25, the total agricultural land ownership in the hands of agriculturalist increased merely by 5 percent, while that of the non-agriculturalist, which included the Chettiars, increased by $35 \% .{ }^{24}$ Deficit rainfall, floods or cattle disease were some of the prime

22 For details on the rising animosity especially over issue of intermarriages between Indian Muslim men and Buddhist Burmese women constructed and covered widely by Burmese Press vide, Majumdar, Rajashree, Constructing the Indian Immigrant to Colonial Burma, Ph. D Dissertation, UCLA, 2013

23 Compiled from Searle, H. F (Commissioner of Settlements and Land records, Burma) Notes on Indian Immigration, 1935, in Burma-Control of Immigration of Unskilled Labourer, EHL Dept., L\&O Branch, Part- IV, pp. 299-374, 1938, NAI; Emigration to Burma, R\&A Dept., Emigration Branch, Feb 1882, NAI; Pillai, E. P. (Labour Member of the Burma legislative council) \& Sundaram, Lanka, (specially appointed to investigate labour conditions in Malay, Ceylon and Burma), Memorandum on Indian Labour in Burma (Confidential), Vizagapatam, EHL Dept, L\&O Branch, Delhi Records, 1934, NAI; Andrew, E. L. J Indian labour in Rangoon, London, OUP, 1933, Chapter-V; Baxter, James, Report on Immigration of Indians into Burma, Rangoon, 1941, Chapter- III.

24 The area occupied by agriculturalist increased from $14,636,046$ to $14,700,611$ acres, while that of the non-agriculturalist increased from 2,512,677 to 3.392,945 acres in between 1914/15 to 1924/25, 
reasons for increased borrowings of the Burmese, against the mortgage of their lands. But it was a succession of bad seasons and poor harvest which incapacitated them to pay back their loans, and lose their lands to the Chettiars.

1930's Global depression was characterised by sharp decline in the rice prices, wages of labourers as well fluctuating exports. ${ }^{25}$ The inability to repay agricultural loans multiplied leading to indebtedness, large-scale de facto land alienation and rural-urban shift. ${ }^{26}$ In Mimbu district itself, Chettiars had an outstanding advance of rupees $2,500,000$ of which they could retrieve only rupees 400,000 . In between 1930-37, whilst the Chettiyar population remained almost stagnant, their agricultural land ownership increased from 570,000 acres to 2,468,000 acres. This cumulated to 25 percent of total agricultural land in the thirteen major rice producing districts of lower Burma, and 50 percent of the total land occupied by non-agriculturalist in the same region. ${ }^{27}$ Despite being numerically few they had immense economic strength in Burma which is also visible from the fact that 83 percent of bankers

Andrew (1933) ibid., p 32

25 There was increased production of rice in various regions including Korea, Japan, Spain, Italy, United States, Siam and Indo-China since the early decades of twentieth century which gave increased competition to the Burmese rice and contributed to its falling prices and fluctuating exports. However, the great-depression had grave implications for the agricultural economy and agrarian structure in Burma, vide, Adas, M, The Burma Delta Economic development and Social change on an Asian Rice Frontier (1852-1941), University of Wisconsin Press, 1974, Chapter 8; Brown, op. cit., Chapter 2 and 3; Cheng, Siok, Hwa. The Rice Industry of Burma, 1852-1940, Kuala Lumpur, University of Malaya Press, 1968, Chapter 8.

26 The agricultural lands were rented by the Chettiars to increasing number of Indian tenants, either for cash or share-produce, which was an important reason for increasing flight of Burmese towards the urban areas in search for employment. This led to blurring of earlier economic division and intensification of competition in both urban as well as rural sphere. The rising anti-Indian and anti-immigration sentiments were flared by the politicians through widescale use of nationalist press and propaganda, leading to series of riots between the two communities throughout the 1930s. Details on riots vide, Mahajani, op.cit., Chapter 3; Siegelman, Phillip, 'Colonial Development and the Chettiyar: A study of ecology of Modern Burma', 1850-1941, Ph. D Dissertation, University of Minnesota, 1962, Chapter 8

27 Baxter (1941), ibid., p. 26-27; Report of Land and Agriculture Committee, Pt. II, p. 39, Mahajani, ibid., p. 20, Siegelman, ibid., p. 257. 
and moneylenders in Rangoon were Indians. Moreover, Indians at 25 percent were second only to Europeans (70 percent) in overall tax payment during the financial year 1931-32, of which 15 percent was contributed by the Chettiars alone. ${ }^{28}$ Furthermore, the networks of this community were not only confined to Burma but spread out to Malaya, Ceylon, Java, Sumatra, Siam and Mauritius. ${ }^{29}$ Chettiyar capitalist and entrepreneurs through their finances and money lending activities not only added an immense value of 'indigenous capital' to the colonies of their existence but also played a crucial role in aiding the functioning of the Maistry intermediaries and stimulating the flow of labourers to Burma.

Further, though about 75 percent of the Indian emigrants to Burma were labourers, largely unskilled, the distinction was that the Indian labourers formed a relatively small proportion of the total population directly involved as plantation labourers or cultivating tenants on the (Rice) plantations in Burma (Table 1). ${ }^{30}$ The Indian labourers were instead largely the ones who manned the industry, dealt with transport development, cleared the streets and built the sewage system in the cities of Burma. They were involved in tasks connected with the new export-oriented rice cultivation such as packing, loading, transporting, bagging, weighing etc. Searle, Commissioner of Settlements and Land records in Burma, stated:

28 Burma Provincial Banking Enquiry Committee Report, Vol. I, 1936, p. 190.

29 Mahajani (1960), op. cit., p. 17-22; By 1936 Chettyars owned 25 per cent of agricultural land in Burma, Lal, Brij.V, Reeves, Peter \& Rai, Rajesh (ed.), The Encyclopaedia of the Indian Diaspora, OUP, 2007, p. 169.

30 Less than 60,000 of the total Indian population of 6.8 lakhs as per 1921 census figures (excluding Arakan), or less than $1 / 10^{\text {th }}$, was the sum of those involved as agricultural labourers and cultivating tenants, S.G Grantham (Census Commissioner) Census Report for 1921 in Andrew (1933), op. cit., p. 25-26; Baxter shows that Indians as non-cultivating owners, cultivating owners, tenant cultivators and agricultural labourers further dropped to 2.7 per cent if one excludes Arakan whose population of settled Chittagonian Muslim agriculturalist was included in the category of emigrant Indians, Baxter (1941), op. cit., p. 26. 
$\therefore$. with the rapid increase in the area cultivated with paddy in Lower Burma, there was a strong demand for agricultural labour and this was filled by Burmans. Simultaneously, the growth of rice milling and shipping industries called for labour in Rangoon and other urban centres and, this was met by immigrant labour from India.'

\section{Table 1-Percentage of Indian cultivating tenants and agricultural labourers in the} total population of Burma (1921 Census) ${ }^{31}$

\begin{tabular}{|c|c|c|c|c|c|c|c|c|}
\hline \multirow{2}{*}{ Race } & \multicolumn{4}{|c|}{ Cultivating tenants } & \multicolumn{4}{|c|}{ Agricultural labourers } \\
\hline & Male & Female & Total & $\%$ & Male & Female & Total & $\%$ \\
\hline $\begin{array}{l}\text { Home } \\
\text { Races }\end{array}$ & 494,032 & 329,281 & 823313 & 97 & 583,068 & 402,002 & 985,070 & $>96$ \\
\hline $\begin{array}{l}\text { Immi- } \\
\text { grant } \\
\text { Indians }\end{array}$ & 16,781 & 1,632 & 18,413 & 2 & 36,255 & 4,048 & 40,303 & $>4$ \\
\hline $\begin{array}{l}\text { Total, all } \\
\text { races }\end{array}$ & 512,362 & 331,178 & 843,540 & 100 & 622,185 & 405,405 & $1,027,590$ & 100 \\
\hline
\end{tabular}

Thus, it would not be wrong to state that the demand in Burma was not mainly for agricultural/ plantation labour but for urban labour, not for raising of a crop, but for its disposal and for the large commercial and industrial needs of the town (Appendix 2). ${ }^{32}$ Moreover, an important point to note here is that though Indian labourers were not involved in significant numbers in the development of plantation agriculture, Burma definitely owed its contemporaneous plantation development, and its global circulation to Indian enterprise and capital leased out to agricultural Burmans by the Indian absentee landowners and capitalists- mainly the Chettiars. Chettiar's contribution in upholding the rice economy of Burma, through their finances and money-lending activities, played a crucial role in defi-

31 Certain classes which were in a minority among the agricultural labour and cultivating tenants' population are excluded resulting in a mismatch of the total population vis-à-vis the total number of home and immigrant races, ELJ Andrew, op. cit., p. 25-26.

32 This division of labour was largely due to difference between character of Indian and Burman, H.F Searle, Notes on Indian Immigration, 1935 in Burma-Control of Immigration of Unskilled Labourer (Part- IV), 1938, NAI, pp. 338-9, 342. 
ning Burma's global image as a leading producer and supplier of rice. Their role also helps us complicate and re-define the Eurocentric notion of western capital being the prime causative factor for the expansion and integration of the world economy.

\section{Patterns of Indian Mobility to Burma}

In between 1911 and 1921, the total flow of Indian migrants to Burma accounted for more than two million, however, the decadal census showed an increase of merely 143,789 Indians in the stock. The 1930 Royal Commission on Labour mentioned that for the years 192229 the total numbers of Indian emigrants who went to Burma were $2,560,000$, but the stock rose by merely 480,000 , all of whom cannot be necessarily labelled as "settlers". ${ }^{33}$ Further, the census figures for the place of birth of the Indian migrant showed that a large proportion of Burman Indians were born in India. ${ }^{34}$ The average percentage of Indians born out of Burma was 81.6 percent in Lower Burma (excluding the Arakan region) in between 1881-1931; and 79.8 percent in between 1901-1931 in Upper Burma. Rangoon, which constituted the bulk of immigrant Indians accounted for a maximum number of born-out with 84.3 percent. If one looks at the percentage of born-outs among immigrant Indians of different regional-linguistic categories it was maximum among Uriyas (97 percent) followed by Telugus (94 percent), Hindustani (84per cent) and Tamils (72 percent). Thus, it would not be wrong to state that one hundred twenty-five years of 'free' and 'unregulated' Indian emigration to Burma was unsettled

33 Report of the Royal Commission on Labour in India, IOR, Printed and Published by His Majesty's Stationery Office, British Library, London, June 1931, Chapter XXIII, pp. 426. The census 1931 considering Port Commissioners records stated the surplus for these 8 years to be 263,000 , Para. 14, Vol. I, 1931 Census. Though both the reports are not unanimous in their figures, but they show synonymous pattern of emigration and help prove the argument.

34 A special Industrial census taken in 1921 of labourers employed industries such as rubber, minerals, wood, metal, rice, oil refining and construction of means of transport revealed that only 4.25per cent of the total Indian labourers born outside Burma intended to reside permanently in the country, Baxter (1941), op. cit., p. 3-4. 
and ephemeral in pattern, and that the emigrants were "Birds of Passage" 35 , and their nature of work was precarious and temporary. (Table 2).

Table 2-Percentage of Indian Population in the Total Population of Burma (excluding Arakan $^{36}$

\begin{tabular}{|c|c|c|c|}
\hline $\begin{array}{c}\text { Cen- } \\
\text { sus }\end{array}$ & $\begin{array}{c}\text { Total Population, } \\
\text { excluding Arakan } \\
\text { Region }\end{array}$ & $\begin{array}{c}\text { Indian Po- } \\
\text { pulation }\end{array}$ & $\begin{array}{c}\text { Percentage of } \\
\text { Indians to the } \\
\text { total }\end{array}$ \\
\hline 1881 & $3,149,253$ & 129,566 & 4.1 \\
\hline 1891 & $7,426,115$ & 282,908 & 3.8 \\
\hline 1901 & $9,728,522$ & 394,379 & 4 \\
\hline 1911 & $11,275,321$ & 545,298 & 4.8 \\
\hline 1921 & $12,302,946$ & 680,087 & 5.5 \\
\hline 1931 & $13,658,611$ & 800,024 & 5.8 \\
\hline 1941 & $15,637,060$ & $6,74,000$ & 4.3 \\
\hline
\end{tabular}

The Agent of GOI in Burma stated in his Annual Report of 1939 '. . . the migratory labour force travels backwards and forward between Indian and Burma at intervals of three years or so throughout the individual working life...'. Most classes of labourers are said to have preferred to stay for some time, usually 3-5 years, because they could not afford more frequent trips and because a sojourn of less than 3 years did not enable them to save 'sufficient money' to take back to their homes. ${ }^{37}$ Moreover, many of these emigrants kept circulating back and forth over a period which conveys that the numbers of new

35 Satyanarayan, Adapa, 'Birds of Passage: Migration of South Indian Labour Communities to South-East Asia 19-20th Centuries A.D', Clara Working Papers, No. 11, Amsterdam, 2001.

36 Chakravarti (1971), op. cit., p. 15-18.

37 Extract from the weekly notes of the Labour Commissioner, Burma, published in supplement to the Burma Gazette, $9^{\text {th }}$ Nov 1935, EHL, 1936, NAI. 
immigrants would have been considerably smaller. This pattern is evidenced by the Burma India Chamber of Commerce estimate that '... only 10 percent of unskilled labourers at rice mills [which was a major employed of migrant labour] were composed of new recruits or first-timers, rest were migratory, i.e. men who went back and forth between India and Burma....' (Emphasis added). ${ }^{38}$ However, since the system remained loosely documented it's impossible to ascertain the accurate percentage of old and new circulating immigrants.

The question that arises is why didn't the Indian labourers wish to settle down in Burma despite consistent colonial claims that the emigration to Burma (and Ceylon) was "free and unregulated". 64.4\% of the Indian male migrants fell between age group 15-40, while 16.7\% were under 15 years. In Rangoon, $71.4 \%$ of Indian males, fell in 15-40 age group. The fact that most of the migrants were young and single males further complicates the question of unsettledness. Why was the immigrant labour population fluidic or unsettled in nature? Why large numbers of labourers kept rotating back and forth? Why were the new labour recruits few?

An explanation for this pattern, which shows us yet another pertinent characteristic of Indian emigration to Burma, was the desire of many labourers to "earn and return". ${ }^{39}$ This desire was shaped not only by the prevalent labour regime, and nature and type of work in Burma under the maistries, which we will discuss ahead, but also on the dynamics of "separation from family and women". Women never formed more than 10 percent of the annual flow of emigrants to Burma which led to highly imbalanced sex-ratio. The average male-female ratio of different Indian immigrant communities in Burma was 19F:100M, worst being the case with Oriyas (3F:100M) and Chit-

38 Of the total Industrial labour force of 187,012 in February 1939, about 60,322 were employed in rice mills (which mostly constituted the Indians), Baxter, op. cit., p. 65 (Emphasis added)

39 Memorandum of information concerning immigrant coolies in Rangoon furnished by Mr. C.H Jones of the preventive service, after enquiry from the Maistries and coolies employed in Rangoon, R\&A Dept., Emigration Branch, 1882, NAI. 
tagonians (9F:100M). Moreover, the employers in Burma, 'natives', shipping companies, and the maistries and their system of recruitment and supervision, directly or indirectly played an essential role in regulating Indian migration, and promoting a 'non-reproductive' unsettled immigrant labour force. Employers preference for a non-reproductive labour force was shaped largely by the concern over the possibility of the emergence of the high level of family wage. For the shipping companies, a permanently settled family labour force meant lower levels of annual traffic. For the maistries a settled labour force not only meant a cap on their recruitment tasks, but also more responsibilities for necessities like separate housing for couples, single men and women, water and medical facilities etc. Employers non-preference, and the nature of available work further helped maistry to pursue a gendered labour-force. Burmans saw the immigrant Indians as direct competitors in various spheres of employment. Especially by the 1930's depression there was an intensification of competition between the locals and migrants which produced intense local instabilities and hostilities. On one hand, the large-scale land alienations, and consequent rural-urban shifts brought the agricultural Burmese in direct confrontation with the urban Indian work-force; and on the other hand, Chettiyar renting out the insolvent lands, for cash or share-produce, not only to Burmese but an increasing number of Indian labourers created a sphere of rural competition and conflicts. It provoked resentments against the unrestricted migration which was widely propagandized by the nationalist press and politicians to pursue larger political goals. It led to riots in various parts of Burma throughout the 1930s, and was marked by increased returns and unsettledness. Yet, a crucial reason behind an unsettled pattern of mobility was the functioning and nature of the maistry system. Maistry's informal regulatory networks of recruitment and emigration through advance-debt and promissory notes/contract, and their 
supervisory role in the colony further maintained the apparently self-adjusting or unsettled emigration pattern. ${ }^{40}$

\section{Functioning and Nature of the Maistry System}

The word Maistry is believed to be derived from the Portuguese word Mestre which literally means a "master". The word was also loosely used to denote a labour contractor who enters into an agreement or written contract with an organization or employers to supply the requisite labour force for a specified period..$^{41}$ The maistry in Burma oversaw the recruitment and supervision of labourers employed in mills, factories, and other commercial and industrial concerns. Maistries were supposedly Indian men of higher or "good castes" who learnt to speak fluent Burmese, and enjoyed an influential position in their native place as well as the place of work..$^{42}$ However, not as prominently as under the kangany system in Ceylon, we learn about the practice of labourers striving to attain or attaining the status of maistry by fulfilling recruitment tasks during shortages. This practice, thus, makes it rational to accept that the maistries also came from the lower castes, and serves to blur the binaries of high and low, caste and class of the mediatory and his work-force.

The structure of the maistries was internally hierarchical, being directly proportional to the strength of labourers employed under him, and operating in coordination. A Gang maistry was at the bottom of the hierarchy which a small group or gang of labourers under him, usually 10-20; Several groups or gangs formed a charge which was controlled by Charge maistry; the man in full control of an entire

40 Disparity in the sex ratio can largely be attributed to the nature of job, vide Andrew, op. cit., pp.16-19.

41 The contract also stated the rate of wages for each class of labor, as well as remuneration to the contractor for his services as recruiter, Kondapi, Chenchala, Indian overseas: 1838-1949, New Delhi: ICWA, OUP, 1951, p. 46.

42 Extract from the weekly notes of the Labour Commissioner, Burma, published in supplement to the Burma Gazette, $9^{\text {th }}$ Nov 1935 in Fno. 189/36-L\&O, 1936, NAI. 
labour organization of a particular firm or company where labourers are employed was called Head maistry; and at the apex of the structure was the Labour Contractor who entered into an written agreement or contract with a firm to supply for the required time period and maintain at its full strength, the labour as stipulated in the contract. He was usually an influential man with strong financial standing having the necessary resources to pay his way through the initial stages of his term of the contract. Wherever a labour contractor was employed he was the man in control with all the other maistries being subordinate to him..$^{43}$ This hierarchical configuration of the maistries was not legally structured, or advertised but was informally regulated by themselves, much to the suitability and convenience of the employers.

Maistries were required to recruit and supply, as per the requirement or shortage, and to supervise the labourers in various industrial and commercial concerns. Though these units were run largely by the Europeans, there were also some non-Europeans- Burmese, Indians and Chinese- investments. The maistries are characterised in the colonial sources as competent and well-suited for the task because of several factors- they were from the same locality as the labourers, and at times had similar social and work profile; in India they were generally recruiting from their native villages/towns/region/caste; in many cases they had kinship ties or friendly relations with labourers recruited or to be recruited, etc. Their networks considerably influenced the decisions of the socially and economically vulnerable prospective emigrants and their families. ${ }^{44}$ However, it's important to assert that during the phase of rising demand of labourers, maistries no longer confined their recruitment tasks only to their villages, kin and friends but extended their networks to one and all whom they could "induce". The presence of shipping companies' recruiting agents and

43 The Encyclopaedia (2007), op. cit., Kondapi, Chenchala (1951), op. cit., p.46; Andrew (1933) op. cit., Chapter-VII.

44 Burma: Stats re quantum of Indian Immigration, Wages, etc., (Confidential), EHL Dept., L\&O Branch, 1936, NAI. 
sub-agents at the ground level as potential competitors only intensified the urge among both to induce labourers at any cost. This led to a significant rise in ill-practices like abduction, misrepresentation of wages, work, facilities and even destinations at times.

Apart from the various socio-cultural, economic and environmental push-pull factors, the most significant inducement offered by the maistry recruiters to the intending emigrants was "cash advances", which had multiple purposes to serve. It included money required to get the intending emigrant out of the shackles of debt-bondage in which they were more than often trapped by the native landlords and moneylenders, and a few months' expense for the family whom the labourer generally left behind before he started earning and presumably 'remitting'. Advances also included the cost of transportation to the colony and the money provided to the recruits as a means of sustenance in the initial period of their stay. Andrews remarked, '...90\% of Indian labourers who come to Burma from Madras Presidency arrive with only a mat and earthen receptacle which contained their food for the voyage'. The amount advanced for merely the liquidation of their debts in India generally ranged between Rupees 50 to 300 , and sometimes went up to Rupees 500. Based on their personal contact with the emigrants Pillai and Sundaram stated in their report that the "three-figure amount of the advances was an underestimate". ${ }^{45}$

The advances represented the amount to be paid off by regular weekly/monthly stoppages or deductions. The objective of the creditors, however, was to keep the debt floating for as long as possible, using fair or fraudulent means. In some instances, these advances were given to the maistry contractor by the employer, per capita, the numbers required for recruitment. It was recoverable by instalments or monthly deductions without interests from the labourer's wages

45 This figure was much less in case of kangany recruited emigrants for Ceylon and Malay ranging to approx. Rs. 100 as reported by Marjoribanks and Marakkyyar Report, Report on Labour Emigration to Ceylon And Malay, Commerce and Industry Dept., Emigration Branch, Jan 1918, NAI. 
when the work bills were presented by the maistry. Generally, the contractors did not ask for or accept advances as they were able to finance the undertaking themselves, having acquired capital during their past operations, or by lending it from their friend- the Chettiars, in which they experienced least difficulty. ${ }^{46}$ The maistry contractors were also involved in loaning amount to the labourers in Burma, which added further to labourer's debt. It is important here not only to note the financial stability enjoyed by the maistry recruiter but also to question as to why did they invest personal money when a ready capital was generally available from the employers to fulfil the labour demands? Why did they prefer the Chettiars over the employers for the advance loans? Why did the labourer keep borrowing once employed in Burma?

To safeguard himself of his contractual obligations to the employers for supplying the requisite number of labourers, the maistries insisted the labourers execute a contract or agreement prior to embarkation. It constituted an undertaking to serve the maistry (not the actual employer), for a given period as well as the acknowledgement of the debt owed by the labourer given as cash advances. This document more than being a statement of facts served as an open-ended weapon of exploitation in hands of the recruiter. Neither the terms of service nor the actual amount of advance-debt owed by the labourers was mentioned on the promissory note/contract at the time the illiterate labourers trusting their kin-recruiter gave their thumb impression on blank stamped forms. ${ }^{47}$ The maistries used this debt-retrieval document not only to extract considerably larger sums from the labourer's wages but also to enslave him for a longer duration based on physical and moral coercion, rather than a fixed tenure based on free will. This was not all as the inflated account was retrieved

46 Andrew (1933), op. cit., p. 37.

47 In signing the document, the labourer would seal his faith, for from that day would begin his bondage, Kondapi, Chenchala (1951), op. cit., p. 47. 
from the labourers charged with compound interest. ${ }^{48}$ Therefore, unlike the Kangany or Indentured system, an important incentive for the maistries loaning their cash as advances was that it gave them the complete freedom in exercising their power over the labourer's body, productivity and mobility. It considerably strengthened their power over the labourers vis-à-vis the employers, and had the potential to increase their earnings by making the labourers directly dependent or debt-bonded.

Thus, based on the advances owed to the maistry, the system mobilised labourers only to immobilize them for longer durations against their free will once they reached the colony. The cash advances freed them from their debts at one space and to one agent only to make them bonded at another space and to a kin-agent. However, it needs to be asserted that maistry's actions were not only the product of his personal desire to grow prosperous at the cost of his labour force but also the consequence of an intense pressure generated by the professional obligation to the 'white employer', who remained aloof of his work-force, for sustained supplies and efficient productivity.

As for the nature of the maistry system, the Annual Reports of Emigration Department, Madras reiterate that emigration to Burma (and Ceylon) was free and unregulated (Italics mine). The Finance Member of Burma stated '...of the immigrant labour into Burma 70 percent was absolutely free labour [Italics mine] coming without the intervention of the Maistry. ${ }^{49}$ It is true that many labourers, apart from other classes of emigrants, came to Burma without being recruited by the maistries in India. However, maistries labour recruiting network were not only confined to India but extended and grew more intense in the immigrant country. Immense powers were entrusted upon the maistries by the employer in the operation of the system, the most abusive being that of "selection and dismissal" and "disbursement of wages". The

48 Chakravarti (1971), op. cit., p. 44.

49 Annual Reports of Emigration Department, Madras, 1890-1919, R\&A Dept. and C\&I Dept., Emigration Branch, NAI; A. Narayan Rao, Indian Labour in Burma, Rangoon, 1933, pp. 28. 
wages, despite being almost double to the Indian rates, were not only irregularly paid but also underwent severe deductions in form ofhigh interest rates on fabricated principal amount, daily/weekly percentage cuts from wages (Kothalu), and commission of a day's wage extracted through 'voluntary donations', exclusive of the number of days in a month the labourer received employment (Paddulu). Thus, all the non-recruited unassisted unskilled labourers, who came freely from India without any contracts or advances, came to be locally recruited and contract bonded. Especially in sectors like sawmills, almost all labourers were recruited locally (in Burma) by maistries. Moreover, for the labourer there was no difference in pay for working day or night, no overtime pays and no weekly off or paid-leave. The working hours had a rigorous schedule of 10-11 hours without break for meals. ${ }^{50}$

All this coexisted with miserable living conditions characterised frequent spread of diseases and epidemics, lack of sanitation and medical aids. The 1925 Health Report from Rangoon recorded 37 and 32 per 1000 as annual death rates for Hindus and Muslims respectively. Deaths at this rate equalled more than three-fourth of the annual excess of Indian immigrants in Burma. The conditions remained so without much improvement throughout 1930's. Charles Innes, Governor of Burma, spoke in 1930, 'No one can read what the Rangoon Health Committee wrote in its report about lodging houses of Rangoon without a feeling of shame...for these lodging houses must be hotbeds of death and diseases (tuberculosis etc)'.

The existent labour regime, thus, made it impossible for the labourers to repay their advances, or to save anything. Any attempt made to save or remit only served to push them towards a more subhuman standard of life. In fact, the struggle for necessities and

50 Rao (1933), ibid., p. 46. In case of European stevedore shipping labour working in gangs- the day and night shift work timings were 6 a.m. to 5 p.m. and 6 p.m. to 5 a.m. respectively, while in the Indian stevedores it was 7 a.m. to 5 p.m. and 7 p.m. to 5 a.m. respectively, without meals break until 1924, Andrew (1933), op. cit., p. 56. 
sustenance in the colony more often forced the labourers to further borrow on high-interest rates from the maistries, local shop-keepers and Chettiyar moneylenders leading to the formation of a vicious cycle of ever-persisting advance-debt. This advance-debt was given legal validity through the Breach of Contract Act which served to restrict, more vigorously, labourer's freedom of mobility and employment.

The Workmen's breach of Contract Act, 1859 was introduced in 1869 in Burma, and remained enforced up till 1925. It rigorously strived to retain the Indian workers in Burma. Through this Act, the maistry could seek legal aid against labourers who deserted or bolted before a full settlement of his debts as mentioned in the signed contracts. The magistrate could order him to perform his contractual work, or sentence the workers who refused to fulfil their contract to imprisonment up to 3 months or fine of the sum of money owed, or both. The Act did not address the root of the problem which produced such actions at the first instance, and never was an attempt made to record and verify what was the terms of service and indebtedness owed by the labourer. The Act also played a role to ensure labourers return to Burma in cases when they were permitted to go home for a sojourn or urgent work. It is interesting to note that many times a family member or relative of a labourer was held back by the maistries, who were generally also aware of the labourers family's whereabout in India. It was to ensure the return of the labourers to repay his debt inducing a phenomenon of, what can be termed as, the hostaged family. This can be stipulated as one of the important reason for lesser new recruits and circulation of emigrants marked by returns and enforced re-returns.

Vaguely defined clauses for criminal prosecution, punishments and fines marked the Breach of Contract Act. It served as an important tool to curb labourer's freedom of employment, bargaining power, and establish absolute control of the maistries over the entire labour market. It empowered maistries to discipline labourers' movements and productivity, and acted as an incentive over their other informal powers at the workplace. Even when it was repealed it did not nullify 
the maistry system on which bulk of Indian emigration to Burma was informally operated. Thus, the system of advances, debt-bondage, contracts and deductions from wages continued with vigour. ${ }^{51}$

An important point to note here is the contradictory nature of state's legal culture. On the one hand the colonial state was evidently not involved in regulating the terms of recruitment, immigration-emigration (post 1870's failed efforts) or of the contracts, thus apparently maintaining the claim that the emigrations to Burma was free and unregulated; while on the other hand the state actively regulated the enforcement of the terms of contract. Both these strands, constructed by the state, played an important role in sustaining as well as strengthening the informal modes of control exercised by the maistries over the labourers. It is also reflective of the fact that the formal/legal and informal regulations under the colonial rule were not exclusive of each other. It rather acted in mutual consonance strengthening immobility, bondage and exploitation of the immigrant labour force. It is important to note here that the ultimate beneficiaries of this state duality were those who had investments in Burma, largely the state and the capitalist-industrialist. The maistry intermediaries who came to be stigmatized as the primary source of all evils against the labourer were, at the first place, customised, promoted and expected to perform the way they did through the power vested in them by the state and capital.

However, apart from the legal duality and intense networks of coercion, there were also elements of freedom, assertions and resistances. For instance, there were a section of labourers who emigrated for agricultural works in groups from Tamil region and worked in gangs without the involvement of the maistry at any level- recruitment, emigration or work. They can be labelled as free labourers in the more real sense of the term. ${ }^{52}$ However, this is not to deny that

51 Vide. Encyclopaedia (2007), p. 56-7; Kondapi (1951), op. cit., p. 48

52 Extract from the weekly notes of the Labour Commissioner, Burma, published in supplement to the Burma Gazette, $9^{\text {th }}$ Nov 1935, 1936, NAI. 
such evidences are rare given the character of work, and the source of workers. Agriculture engaged fewer of the total Indian emigrants, and was composed mostly of Chittagonians. Most of the migrants continued to be a part of the urban work-force in Burma where an intensified network of maistries in all spheres of employment was difficult to bypass.

Moreover, there existed a crucial network of the free Indian migrants of other classes and castes who were involved in trade and mercantilist activities (Chettiars, Sindhis etc), professional services (teachers, doctors, clerks etc), government administration, colonial army and police. Though by 1930s-40s, their freedom of work and mobility was challenged by parallel instances of increasing discriminatory motions and ordinances. A series of measures were introduced like the: Land Alienation Act, Agricultural Debt ReliefAct 1948, Agricultural Bank Act 1948, Standard Rent Act and Tenancy Disposal Act 1947-48 etc, all of which were aimed against Indian money-lending and land-owning groups esp. the Chettiars, and safeguarding the interest of the Burmese agriculturalists..$^{53}$ Further, Land Nationalisation Act 1948, Burma Foreigners Act 1948, and Buddhist Women's Special Marriage and Succession Act also caught the anxiety of Indians. There was also an early bill to include Burman British subjects as 'foreigners' for registration, which was ruled ultra vires by the speaker. ${ }^{54}$ Hutchings, the Agent of GOI in Burma stated 'jealousy of Indian success in trade and commerce, the universal dislike of the borrower for the money-lender, the racial incom-

53 The combination of these measures eliminated the Chettiars interest in Burma, the capital value of which was estimated around 60 million pounds plus accrued interest of 30 million pounds or more, Chakravarty, op. cit., p.177. The GOI assured (without much success) that it will safeguard interests of all Indians including Chettiars in Burma as provided under section 44-54 and 134-138 of Government of Burma Act, 1935 even after separation, Question and Answer in Legislative Assembly-Burma, EHL Dept., L\&O Branch, 1936, NAI

54 Annual Report of the Agent of GOI in Burma for year ending Dec 1939, 1940, NAI 
patibility...in the times of trade depression combined with national and political stimulations broke out into violent actions'. ${ }^{55}$

As for the labour resistances, up till the depression of the 1930s, they were largely unorganized and more individualistic in nature. It often took forms of desertion, deaths and dual diasporic activities across neighbouring regions of Siam, Sumatra, Malaya etc, which were fast enough not to be traced by the authorities. Many times they were caught, returned, fined, flogged and imprisoned. Untraceable runaways to India, to newer areas of employment, and lack of newer recruits were other manifestations of labour resistance. An everyday form of resistances also included absconding and delaying tasks given. Roots of organized union activities by 1930 s lay in the urban-rural shift, and the growing competition and antagonism between the Indians and Burmans. The rise of nationalist sentiments in Burma was built upon not only anti-colonial, but also anti-Indian and anti-immigration sentiments. It manifested itself in Burmese picketing and riots which in turn provided a voice to Indian opinions too, in the print and in form of organized union activities.

After the separation of Burma from British India in 1937, Indian immigration came to be regulated by the Burma Immigration Order of 1937. It prescribed no restrictions on the entry of Indians into Burma, except those in force immediately before the commencement of the Government of Burma Act 1935. Three years was period prescribed for the Order to be upheld or until 12 months have elapsed from the submission by the Governor of Burma to the Governor-General of India of the notice to terminate the operation of the Order, whichever is longer. ${ }^{56}$ This led to increasing instance conflicts and violence against

55 Extract from the Report of the Agent of GOI in Burma on his visit to upper Burma and Shan states, Nov-Dec 1939 in Burma Riot Inquiry Committee Report (1939), NAI; Confidential Note by Dr. H Bernardelli on Indian Emigration in Burma, Jan 1940, NAI, pp. 208, 213-14.

56 Government of Burma-Immigration Order in Council, IOR/ M/1/11, 1937, British Library, London. 
Indians in various parts of Burma, ${ }^{57}$ and as a result appointment of the Baxter commission to ascertain the future of Indian immigration in 1939. The commission gave primacy to the prevailing sentiments, rather than the statistical inferences. It called for regulation on the migration of Indian labourers through passports, visas, permits and qualifying tests through an agreement which led to formulation of Immigration Order of 1941. However, the Order could not come into effect owing to the Japanese occupation of Burma from 1942. It marked a huge exodus of Indians through the forested land. About $50 \%$ of the total stock fled Burma, of which about 10-15 percent perished trekking back to India suffering heavy casualties. Those who remained lost all their wealth and belongings in looting and war damage, and many ended up in forced labour gangs run by Japanese Military. Japanese occupation of Burma was marked by coerced labour with inhuman conditions of work, sanitation and living leading to high 108 mortality, diseases and deaths. Conditions of livelihood for returnees were equally worse as India was marred by political and environmental turmoil. The Quit India movement, collapse of rice trade, food shortage and the famine of 1943 coupled with nature's fury in 1942 when the cyclone hit the eastern coast of Bengal, flooding the fields and destroying of the crops, led to mass starvation, and killed nearly three million people in British India. The impact of global events across the Bay not only led to a reconfiguration of frontiers, political units and the nation-state but also induced new ideas of citizenship,

57 For detailed discussion on riots vide, Burma Riots: Situation Report, IOR/M/3/513; Use of Tear Gas by Rangoon Police to control disturbances, IOR/M/3/619; Burma Riot Inquiry Committee Interim and Final Report, IOR/M/3/514, British Library, London. There were multiple riots in 1930-31 and 1938-39 against Indian in various spheres of employments like dockyard labourers, miners and sappers, mill owners, Chettiyar traders, shop keepers, Chittagonian agriculturalist and coolies. 
nationalities and belonging. The century of mass emigration to Bur$\mathrm{ma}$ and the Maistry system went into abrupt decline.

\section{Conclusion}

The article attempted to analyse the qualitative and quantitative distinctiveness of Indian emigration to Burma. The aim was to complicate the historiographical parameters which define the characteristics of colonial Indian migration, and broaden the thematic discussions on the form, content, substance, nature and spaces of Indian migration. The study helps shift our focus from the overarching shadow of Indentured sugar colonies in Caribbean and Pacific, which have been the dominant regions of study of Indian migration, towards the British colonies in the Indian Ocean's Bay of Bengal rim, which was the recipient of the bulk of colonial Indian migrations. The overt impetus on the Indentured characteristics as defining features of colonial Indian migration, is complicated by the fact that majority of the Indian migrants to Burma came from the peninsular part of British India-Telugus, Oriyas and Tamils, were not majorly plantation labourers, and included a substantial number of non-labouring classes.

This mobility remains crucial not only because of its quantum but also because of its pattern. The movement had a strong circulatory and ephemeral characteristic with $80-90$ percent returnees every year. Analysis of this persistent pattern in South Asian and Southeast Asian experiences has largely eluded the Eurocentric narratives with its overt focus on the trans-Atlantic experiences. As explained, this pattern in Burma was established partly due to the nature of work in Burma and partly because of the conditions in places of origin of the migrants. Yet the crucial reason for the persistence of this pattern was the maistry system. The maistry system with its ubiquitous networks of advances and debt-contract, apart from the deplorable work and living conditions, functioned to maintain the apparently 'self-adjusting' and 'free' (meaning thereby non-indentured and non-government supervised) emigration pattern. 
The article engages with the non-European mediations: the role it played in stimulating migration flows, and the production and circulation of commodity. British intervention in Burma and its efforts to promote mobility were crucial start-ups for generating the migration momentum. However, to presume that the migration flows were the exclusive result of European expansion and intervention would be an overstatement. The indigenous players, most importantly the networks of the maistry recruiter cum supervisor and the Chettiars merchants and bankers, apart from the village moneylenders, shipping agents and sub-agents, stimulated, regulated and sustained the Indian mobility to Burma. Chettiars not only also acted as the backbone of the Burmese agricultural economy, through their massive loaning and financing structure, but also stimulated large-scale Indian emigration with great success through their financing of Maistry's recruitment activity, individual labourers mobility, and number of smaller and medium sized up-country mills. They facilitated the emergence of Burma as one of the largest rice producing regions of the world, and that of rice as an important crop for global circulation and consumerism. The idea here is not to establish the complete functional autonomy of indigenous men and capital from the hegemonic presence of its European and north-Atlantic counterparts. It is rather intended to draw attention towards the much-overlooked presence and contribution of non-European entities in regulating migrants, migration and materiality; and to underline the interconnections and entanglements of European and non-European contribution to the expansion and integration of global economy in the age of mass migrations.

The article also endeavours to complicate notions of freedom-unfreedom as far as migration to Burma was concerned. More recently, in attempt to counter the dichotomy of free European-unfree non-European migrations, and to provide an agency of freedom to non-European migratory experiences, scholars have emphasised upon the maistry and kangany systems as it involved non-European intermediary agencies, freedom from government supervision, and 
independent networks of family, friends and villagers. ${ }^{58}$ In this article, I have attempted to convey that notions of freedom and unfreedom need to be qualified for each class of migrants, temporally as well as at each step of migration process i.e. recruitment, en route, and work and life in the colony. Maistry system reveals an intense network of coercion and exploitation faced by the emigrant labourers at various steps, co-existing with spurts of freedom, assertions as well as resistance. The experiences of the labourers as well as other classes of migrants, over the century, tend to defy any rigid categorization. The article strongly asserts the difficulty in working with watertight dichotomies of choice-force, freedom-coercion or regulated-unregulated in so far as the migration was concerned. Instead it's urged to see it as functioning along a spectrum of positions from free, voluntary and unregulated migration at one end to constrained, regulated and coerced migration at the other.

\section{SELECT BIBLIOGRAPHY}

\section{National Archives of India}

Emigration Branch (1870-1923): Revenue, Agriculture and Commerce Department; Home, Revenue and Agriculture Department; Revenue and Agriculture Department; Commerce and Industry Department; Commerce Department; Revenue and Agriculture Department.

Overseas Branch, and Land \& Overseas Branch (1923-38)- Education, Health and Land Department.

\section{British Library, London}

Annual Files of the following Departments 1882-1929: Revenue, Statistics and Commerce, 1882-1887; Revenue and Statistics, 1887-1921; Commerce and Revenue, 1922-1954; Economic and Overseas, 1924-1929

58 Mckeown (2004), ibid., p.10; For more critical perspective on Eurocentrism and free-unfree nature of migrations vide, Mohapatra, Prabhu, 'Eurocentrism, Forced Labour, and Global Migration: A Critical Assessment', IRSH 52, 2007, p. 110-115; Lucassen, Jan and Lucassen, Leo, Migration, Migration History, History, Old Paradigms and New Perspectives, P.Lang, 1999, p. 1-37. 
Burma Office Records (1932-48)

India Office Records and Private Papers: Commissions, Committee and Conference Records (1895-1948)

Public and Judicial Dept. collection (1921-41): Public and Judicial (1921-41), Political (1941-44), Political (British India) (1944-47), Political (General) (1946-47).

\section{Secondary Sources}

Adas, M, The Burma Delta Economic development and Social change on an Asian Rice Frontier (1852-1941), University of Wisconsin Press, 1974.

Amrith, Sunil, Crossing the Bay of Bengal: The furies of Nature and Fortunes of Migrants, Harvard University Press, USA, 2013.

Andrew, E. L. J Indian labour in Rangoon, London, OUP, 1933.

Brown, Ian, Colonial Economy in Crisis: Burma's rice cultivators and World Depression of 1930s, Routledge Curzon, London and New York, 2005.

Chakravarti, N.R, The Indian Minority in Burma: The Rise and Decline of An Immigrant Community, OUP, London, 1971.

Cheng, Siok, Hwa. The Rice Industry of Burma, 1852-1940, Kuala Lumpur, University of Malaya Press, 1968.

Davis, Kingsley, Population of India and Pakistan, PUP, 1951.

Dirk Hoerder, Dirk, Cultures in Contact: World Migrations in the Second Millennium, Durham, N.C.: Duke University Press, 2002.

Ferrars, Max and Ferrars, Bertha, Burma, $2^{\text {nd }}$ Edition, London and New York, 1901.

Hall, D. G. E., A History of South-East Asia, New York: St. Martin's Press, 1955.

Kondapi, Chenchala, Indian overseas: 1838-1949, New Delhi: ICWA, OUP, 1951.

Lal, Brij.V, Reeves, Peter \& Rai, Rajesh (ed.), The Encyclopaedia of the Indian Diaspora, OUP, 2007.

Lewis, W. Arthur (ed.), Tropical Development 1880-1913, Studies in Economic Progress, Gresham Press, Great Britain, 1970.

Lucassen, Jan and Lucassen, Leo, Migration, Migration History, History, Old Paradigms and New Perspectives, P.Lang, 1999. 
Mahajani, Usha The Role of Indian Minorities in Burma and Malaya, Bombay, Vora \& Co., 1960.

Majumdar, R.C, Ancient Indian Colonization in South-East Asia, Baroda, Oriental Institute, 1955.

Majumdar, Rajashree, Constructing the Indian Immigrant to Colonial Burma, Ph. D Dissertation, UCLA, 2013

Mckeown, Adam, 'Global Migration' (1846-1940), Journal of World History, Volume 15, Number 2, University of Hawai'i Press, June 2004.

Mohapatra, Prabhu, 'Eurocentrism, Forced Labour, and Global Migration: A Critical Assessment', IRSH 52, 2007.

Northrup, David, Indentured Labour in the Age of Imperialism (1834-1922), CUP, 1995.

Report of the Royal Commission on Labour in India, IOR, Printed and Published by His Majesty's Stationery Office, June 1931.

Satyanarayan, Adapa, 'Birds of Passage: Migration of South Indian Labour Communities to South-East Asia 19-20th Centuries A.D', Clara Working Papers, No. 11, Amsterdam, 2001.

Siegelman, Phillip, 'Colonial Development and the Chettiyar: A study of ecology of Modern Burma', 1850-1941, Ph. D Dissertation, University of Minnesota, 1962.

Tinker, Hugh, The Banyan Tree: Overseas Emigrants from India, Pakistan and Bangladesh, OUP, 1977.

Yegar, Moshe Muslims of Burma - A Study of a Minority Group, Heidelberg, 1972 Abbreviations:

C\&I Dept. - Commerce and Industry Department

EHL Dept. - Education, Health and Land Department

Fno. - File Number

GOI- Government of India

IOR - India Office Records

L\&O Dept. - Land and Overseas Department

NAI - National Archives of India

Pros. No. - Proceeding Number 
R\&A Dept. - Revenue and Agriculture Department 


\section{Appendix - 1}

\begin{tabular}{|c|c|c|}
\hline $\begin{array}{l}\text { Indian } \\
\text { Emigrants }\end{array}$ & $\begin{array}{l}\text { Ports and Areas from where } \\
\text { emigration occurred }\end{array}$ & Spheres of Production in Burma \\
\hline Telugus & $\begin{array}{l}\text { Coromandel ports namely } \\
\text { Coconada, Vishakhapatnam, } \\
\text { Bimlipatam, Calingapatam, } \\
\text { Barua and Gopalpur. } \\
\text { They mainly belonged to } \\
\text { Ganjam, Vishakhapatnam } \\
\text { and Godavari regions of } \\
\text { Andhra. }\end{array}$ & $\begin{array}{l}\text { As unskilled labour employed in mills, fac- } \\
\text { tories and shipping companies. As porters, } \\
\text { rickshaw pullers and hand-cart men. } \\
\text { In crop-cutting operations of the agricul- } \\
\text { turalists. Telugus from Nellore district } \\
\text { provided bulk of the sweepers found in } \\
\text { Rangoon, and its suburbs. }\end{array}$ \\
\hline Oriyas & $\begin{array}{l}\text { Ganjam district of Madras } \\
\text { Presidency (about 66per } \\
\text { cent of Oriyas) and coastal } \\
\text { districts of Orissa through } \\
\text { mainly Coromandal ports. }\end{array}$ & $\begin{array}{l}\text { Provided the bulk of the labour required by } \\
\text { the Railway and Public Works Department } \\
\text { for construction and earthwork. They were } \\
\text { also employed in Mills, Dockyards and } \\
\text { Foundries both as skilled and as unskilled } \\
\text { workers. }\end{array}$ \\
\hline Tamils & $\begin{array}{l}\text { Southern districts of the Ma- } \\
\text { dras Presidency like Ramnad } \\
\text { and Tanjore etc. }\end{array}$ & $\begin{array}{l}\text { The lower middle as well as the lower } \\
\text { classes were involved in the rice mills and } \\
\text { as agricultural workers. } \\
\text { The Middle class of Tamils were employed } \\
\text { in Government clerical works as well as } \\
\text { railway and mercantile offices. } \\
\text { Chettyars came largely from Chettinad in } \\
\text { Madras }\end{array}$ \\
\hline
\end{tabular}




\begin{tabular}{|c|c|c|}
\hline Hindustanis & $\begin{array}{l}\text { United Provinces (Sultanpur } \\
\text { and Fyzabad districts). Emi- } \\
\text { grating via. Calcutta port }\end{array}$ & $\begin{array}{l}\text { Comprised of Hindu and Mohammadan } \\
\text { Chapraisis, Peons or Darwans. Many were } \\
\text { exceptionally successful as petty vendors } \\
\text { also. }\end{array}$ \\
\hline Bengalees & $\begin{array}{l}\text { 2) Inland route or through } \\
\text { Chittagong port - Most- } \\
\text { ly Muslim peasants and } \\
\text { agricultural labourers. Fewer } \\
\text { Bengalees. }\end{array}$ & $\begin{array}{l}\text { Educated got employed in a subordinate } \\
\text { capacity in railway or local fund service, or } \\
\text { in mercantile offices mostly in the clerical } \\
\text { line and some even as shop-keepers and } \\
\text { traders } \\
\text { Chittagonians were largely employed as } \\
\text { ship and launch crew labourers as well as } \\
\text { sampan-wallah and small craft traffic. They } \\
\text { were also employed as Paddy harvesters, } \\
\text { and in mills and dockyards as drivers, } \\
\text { tindals, oilmen or khalasis. }\end{array}$ \\
\hline Others & $\begin{array}{l}\text { Punjabis, Marwaris, Gujratis } \\
\text { Multanis, Nepali and Bhutia }\end{array}$ & $\begin{array}{l}\text { Punjabis found employment chiefly as } \\
\text { artificers, turners, overseers, etc., in rail- } \\
\text { ways, motor workshops, dockyards and } \\
\text { foundries. } \\
\text { Marwaris, Gujratis and Multanis Mer- } \\
\text { chant-Bankers were confined to urban } \\
\text { areas - Mandalay, Prome, Rangoon and } \\
\text { Moulmein; } \\
\text { Nepali and Bhutia were Principally traders. }\end{array}$ \\
\hline
\end{tabular}




\section{Appendix 2-Classification of Economic functions of All Races in Burma}

\begin{tabular}{|c|c|c|c|c|c|}
\hline Economic functions & All races & $\begin{array}{l}\text { Indigenous } \\
\text { races }\end{array}$ & $\begin{array}{l}\text { Indians } \\
\text { Born in }\end{array}$ & $\begin{array}{l}\text { Indians } \\
\text { Born out }\end{array}$ & $\begin{array}{l}\text { Oth- } \\
\text { ers }\end{array}$ \\
\hline A. Cultivating land-owners & 100 & 97.07 & 0.19 & 1.06 & 1.68 \\
\hline B. Cultivating tenants & 100 & 95.08 & 0.61 & 3.44 & 0.87 \\
\hline C. Agricultural landlords & 100 & 92.84 & 1.06 & 5.05 & 1.05 \\
\hline D. Herdsmen & 100 & 46.68 & 3.76 & 44.05 & 5.51 \\
\hline E. Fishers and hunters & 100 & 91.91 & 0.10 & 4.72 & 3.27 \\
\hline F. Clerical workers & 100 & 47.50 & 4.27 & 37.93 & 10.30 \\
\hline $\begin{array}{l}\text { G. Managers and officials } \\
\text { Of organised industrial } \\
\text { undertakings }\end{array}$ & 100 & 57.81 & 3.53 & 17.90 & 20.76 \\
\hline H. Craftsmen & 100 & 66.83 & 1.83 & 23.16 & 8.18 \\
\hline $\begin{array}{l}\text { I. Unskilled and semiskilled } \\
\text { Labourers excluding sweep- } \\
\text { ers \& scavengers }\end{array}$ & 100 & 47.97 & 1.80 & 45.39 & 4.84 \\
\hline $\begin{array}{l}\text { K. Technical experts \& } \\
\text { Professional classes exclud- } \\
\text { ing } \\
\text { Medical and religion }\end{array}$ & 100 & 65.88 & 1.90 & 15.18 & 17.04 \\
\hline L. Traders \& shop assistants & 100 & 50.39 & 2.23 & 31.04 & 16.34 \\
\hline M. Rentiers & 100 & 89.86 & 0.83 & 5.22 & 4.09 \\
\hline $\begin{array}{l}\text { N. Army, Navy, Air Force } \\
\text { and } \\
\text { Police. }\end{array}$ & 100 & 50.12 & 1.83 & 41.07 & 6.98 \\
\hline $\begin{array}{l}\text { O. General Public service } \\
\text { including Local bodies }\end{array}$ & 100 & 91.65 & 0.37 & 0.99 & 6.99 \\
\hline
\end{tabular}




\begin{tabular}{|l|l|l|l|l|l|}
\hline P. Religion & 100 & 64.16 & 0.57 & 20.33 & 14.94 \\
\hline Q. Medicine & 100 & 85.45 & 1.12 & 9.28 & 4.15 \\
\hline R. Sweepers & 100 & 3.87 & 5.38 & 90.38 & 0.37 \\
\hline S. Miscellaneous & 100 & 89.86 & 0.98 & 7.32 & 1.84 \\
\hline $\begin{array}{l}\text { T. Insufficiently described- } \\
\begin{array}{l}\text { Manufacturers, busi- } \\
\text { ness-men }\end{array}\end{array}$ & 100 & 18.24 & 4.42 & 61.20 & 16.14 \\
Contractors & 100 & 74.46 & 0.54 & 21.20 & 3.80 \\
\hline U. Others & & & & & \\
\hline
\end{tabular}

Source: Confidential Note by Dr. H. Bernardelli on Indian Emigration in Burma, Jan 1940 in Burma-Control of Immigration of Unskilled Labourer, (Part-III, pp. 144-298), Fno. 144-1/38-LEO, 1938, NAI.

Recebido em: 16/02/2017 - Aprovado em: 23/03/2018 